\title{
Hypoxanthine and Oxygen Induced Lung Injury: A Possible Basic Mechanism of Tissue Damage?
}

\author{
O. D. SAUGSTAD, ${ }^{(39)}$ M. HALlMAN, J. L. ABRAHAM, B. EPSTEIN, C. COCHRANE, AND \\ L. GLUCK \\ Department of Pediatrics, Division of Neonatal/Perinatal Medicine and Pathology, University of California San \\ Diego and Scripps Clinic and Research Foundation, La Jolla California, USA
}

\begin{abstract}
Summary
Lung injury was induced in young rats by a continuous infusion of hypoxanthine intravenously and breathing $100 \%$ oxygen for $48 \mathrm{~h}$ (group 1). Control animals were rats infused glucose and breathing $100 \%$ oxygen (group 2), rats infused hypoxanthine in room air (group 3), and untreated rats (group 4). In group 1 rats interstitial and alveolar edema was found with a tendency toward marked margination of polymorphonuclear neutrophils in small vessels $(P<0.025$ compared with group 2$)$. The main elastase

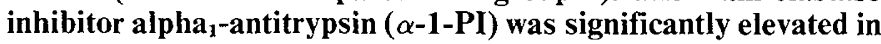
group 1; 2-, 3- and 5-fold, respectively, when compared with groups 2,3 , and 4 . The surfactant phopholipids from alveolar lavage were normal in all groups. The protein-rich fraction of the lavage fluid from group 1 rats inactivated, however, the surface properties of lung surfactant. Minimum surface tension in group 1 rats was $14.5 \mathrm{dyn} / \mathrm{cm}$ compared with $7.0 \mathrm{dyn} / \mathrm{cm}$ in group 2, $2.9 \mathrm{dyn} / \mathrm{cm}$ in group 3 and $3.5 \mathrm{dyn} / \mathrm{cm}$ in group $4(\mathrm{P}<0.05$, group 1 and 2 versus 4 ). We conclude that the combination of hypoxanthine and high levels of oxygen causes lung injury, possibly via free oxygen radicals. We discuss the possibility that these findings demonstrate a basic pathogenetic mechanism for the hypoxic-hyperoxic insult and can contribute to the understanding of pathogenesis of a variety of diseases both in pediatrics and adult medicine.
\end{abstract}

\section{Abbreviation}

$\alpha-1-P I$, alpha $_{1}$-antitrypsin

Free oxygen radicals have been shown to destroy cell membranes by lipid peroxidation $(3,8,11,21)$. It has been suggested that such radicals play an important role in the pathogenesis of the acute and chronic lung damage among patients treated with oxygen. Many authors have, however, suggested that oxygen must be combined with other more or less unknown factors, before injury occurs $(14,27)$.

Recently, it has been shown that the hypoxanthine/xanthine oxidase system generates free radicals (7), and that this system potently induces inflammatory changes both in the hamster cheek pouch (22) and the rat lung (16). Further, it has, by now, been well established that hypoxanthine accumulates in tissues (33), plasma $(30,32,34,35)$, and other body fluids $(12,23,25)$ during hypoxia. When high concentrations of oxygen are administered to the hypoxic patient, large amounts of free radicals may be produced by the hypoxanthine/xanthine oxidase system.

We, therefore, have raised the question whether the combination of hypoxanthine and oxygen is more damaging than high oxygen alone to the lung. In the present study we evaluated this by investigating experimentally the effect on the rat lung to $100 \%$ oxygen exposure with simultaneous intravenous hypoxanthine infusion.

\section{MATERIALS AND METHODS}

Young female rats of the Wistar strain, weighing 170-230 g, were used. Four groups were investigated. Group 1, rats infuscd continuously with $5 \mathrm{mM}$ hypoxanthine dissolved in $5 \%$ glucose and exposed to $98-100 \%$ oxygen $(n=10)$. Group 2 , rats infused continuously with $5 \%$ glucose and exposed to $98-100 \%$ oxygen $(n=9)$. Group 3, rats infused continuously with $5 \mathrm{mM}$ hypoxanthine dissolved in $5 \%$ glucose in room air $(n=5)$. Group 4, untreated rats $(n=7)$. Infusion rate was approximately $80 \mathrm{ml}$. $\mathrm{kg} \cdot 24 \mathrm{~h}^{-1}$ and all experiments lasted $48 \mathrm{~h}$. The infusions were performed with a Havard infusion pump via a tail vein. A millipore filter (pore size, $0.45 \mu \mathrm{m}$ ) was included in the infusion line. The rats were fed with normal laboratory food and had access to water ad libitum before the experiments. During experiments they were not given food or extra water.

Rats in groups 1 and 2 were put into a sealed transparent chamber continuously flushed with $\mathrm{O}_{2}$. The oxygen concentration was confirmed by direct measurements. The $\mathrm{CO}_{2}$ was adsorbed to $\mathrm{Ca}(\mathrm{OH})_{2}$. Humidity was maintained by having an open water surface within the chamber. The experiments were performed at room temperature.

The rats were sacrificed with an intravenous bolus of Nembumal. The trachea was then cannulated and $4 \mathrm{ml}$ of isotonic saline introduced to the airways, followed by gentle suction. During the first wash approximately $3 \mathrm{ml}$ was recovered. One milliliter of the lavage fluid was used for elastase and antielastase $(\alpha-1-\mathrm{PI})$ determinations. Protein concentration of the lavage fluid was measured according to Lowry et al. (20). The lungs were washed another three times with $6 \mathrm{ml}$ of saline each time. Approximately 5-6 $\mathrm{ml}$ were recovered each time and the lavage fluid from all four washes were combined (except the $1 \mathrm{ml}$ for elastase, $\alpha-1-\mathrm{PI}$, and protein determinations). The lavage fluid for elastase $/ \alpha-1$-PI and protein determination was centrifuged at $1500 \mathrm{~g}$ for $10 \mathrm{~min}$. The supernatant was frozen at $-20^{\circ} \mathrm{C}$ until analysis. Lavage fluid used for surfactant measurements was spun at $150 \mathrm{~g}$ for $10 \mathrm{~min}$. One-half of the supernatant was used for analysis of phospholipids and surface activity. The other half was centrifuged at $8000 \mathrm{~g}$ for $2 \mathrm{~h}$. The pellet was used for isolation of the surface active lipid protein fraction, called lung surfactant, by sucrose density gradient centrifugation (10).

Elastase was determined after cleavage of methyloxysuccinylL-Ala-L-Ala-pro-L-Val-p-nitroalinide at $20^{\circ} \mathrm{C}$ for $20 \mathrm{~min}$. Cleavage of the substrate was read at $410 \mathrm{~nm}$. The background activity was subtracted (4). $\alpha$-1-PI was determined with the same assay at $37^{\circ} \mathrm{C}$ except that a proper amount of porcine pancreatic elastase was added to the lavage fluid. The free elastase activity 
could, hence, be used to calculated the $\alpha$-1-PI activity. For details see reference numbers 18 and 26 .

Surfactant phospholipids were analyzed by two dimensional thin layer chromatography, and the individual phospholipids were quantified on the basis of the phosphorous content (9). Disaturated lecithin was determined as described by Mason et al. (24). The surface properties of the crude surfactant fraction and the surfactant fraction purified by sucrose density gradient were analyzed using a modified Wilhelmy balance at $37^{\circ} \mathrm{C} \mathrm{(13).}$ The surface properties were further tested by using the pulsating bubble surfactometer (6).

The lung lavage supernatant obtained by centrifugation, as described previously, was added to the pulsating bubble chamber together with natural surfactant isolated from lavage of rabbit lung (10). The resulting bubble $\left(\mathrm{r}_{\max }=0.55 \mathrm{~mm}, \mathrm{r}_{\min }=0.40\right.$ $\mathrm{mm}$ ) was pulsated at a frequency of $0.33 \mathrm{~Hz}$ for $1 \mathrm{~min}$ at $36.7^{\circ} \mathrm{C}$ and the collapsing pressure of the bubble was measured continuously. Thereafter the minimum surface tension was calculated according to the LaPlace law, $\mathrm{p}=2 \mathrm{~h} / \mathrm{r}$, were $p$ is the collapsing pressure, $h$, the surface tension, and $r$ the radius of the bubble.

The infused hypoxanthine solution was tested with regard to purity by high pressure liquid chromatography (38), and it was shown that the infused solution gave only one peak at $254 \mathrm{~nm}$ indicating purity of the solution. Plasma hypoxanthine was determined in some rats at the end of the experiments with a method previously described by one of us (31). All the rat slices for light microscopy were taken from the periphery of the lower left lung before alveolar washing.

\section{RESULTS}

All the rats survived the experiments. Animals put into the oxygen chamber developed respiratory distress with chest wall retractions. The mean plasma hypoxanthine level of six rats from group 1 at the end of the experiment was $5.5 \pm 7.1 \mu \mathrm{m}$ (SD) (V. Jugularis plasma). Normal plasma hypoxanthine level of rats ranged between $0-3 \mu \mathrm{M}$ with the present method.

Morphology. Five normal rats had lung tissue without edema or hemorrhage, although some congestion was seen (group 4). One of these animals had margination of polymorphonuclear neutrophils in small vessels and capillaries. In both group 1 and 2 there was evidence of interstitial and alveolar edema and hemorrhage. In group 1 rats such changes were found in $8 / 10$ compared with $1 / 6$ in group 2 animals $(P<0.025$, Chi square test). In group 1 there was a tendency toward marked margination of polymorphonuclear neutrophils in small vessels and capillaries as well. In the five rats of group 3, the lungs did not differ from those of the non-treated rats.

Total protein. The total protein concentration of the lavage fluid showed approximately three times higher levels in group 1 compared with group 3 and $4(P<0.001)$ and a 2-fold increase compared with group $2(P<0.01, t$ test) (Table 1$)$.

Elastase and $\alpha-1-P I$. There was no detectable free elastase activity in the lavage fluids; however, the elastase inhibitor, $\alpha-1$ PI, was present at different concentrations in the various groups. Group 1 rats had a double level compared with the level in group $2(P<0.005)$ and a 3 -fold $(P<0.01)$ and 5 -fold $(P<0.05)$ increase compared with groups 3 and 4 , respectively. The values

Table 1. Total protein in lavage fluid

\begin{tabular}{cc}
\hline Group no & Protein $(\mathrm{mg} / \mathrm{ml})$ \\
\hline 1 & $0.74 \pm 0.34^{*}$ \\
$2 \dagger$ & $0.35 \pm 0.15$ \\
$3 \ddagger$ & $0.23 \pm 0.08$ \\
$4 \ddagger$ & $0.24 \pm 0.11$ \\
\hline
\end{tabular}

$*$ Mean $\pm \mathrm{SD}$.

$\dagger 1$ vs $2, P<0.01$.

$\ddagger 1$ vs 3 and $4, P<0.001$.
Table 2. Alpha $a_{1}$-antitrypsin ( $\left.\alpha-1-P I\right)$ in lavage fluid

\begin{tabular}{cc}
\hline Group no. & $\alpha$-1-PI $(\mu \mathrm{g} / \mathrm{ml})$ \\
\hline 1 & $16.0 \pm 8.5^{*}$ \\
$2 \dagger$ & $7.6 \pm 5.6$ \\
$3 \$$ & $4.8 \pm 5.4$ \\
$4 \S \|$ & $3.3 \pm 2.0$ \\
\hline
\end{tabular}

$*$ Mean $\pm \mathrm{SD}$.

$\dagger 1$ vs $2, P<0.005$.

$\ddagger 1$ vs $3, P<0.01$.

$\S 1$ vs $4, P<0.005$.

$\| 2$ vs $4 P=0.005$.

of group 2 were significantly elevated compared with group 4 ( $P$ $=0.005$ ) whereas the values in group 3 and 4 did not differ significantly.

Because there has been data published showing that the elastase inhibitor can be inactivated by oxidation (5), we tested the level both with an immunologic technique and using the chromogenic substrate. On the basis of these studies we were unable to document an inhibition of $\alpha-1$-PI activity. The levels of $\alpha$-1-PI measured with chromogenic substrate are given in Table 2.

Surfactant. Table 3 shows the distribution of the major phospholipids in lavage fluid of the groups. There were no significant differences among the four groups.

Table 4 contains data on the surface properties of the crude alveolar lavage of the lipid protein complex isolated from the lavage fluid. Although the lipid protein complex was surface active regardless of treatment in vivo, the crude alveolar lavage was significantly less surface active after hypoxanthine and $\mathrm{O}_{2}$ treatment when compared with all the other groups. Hyperoxia alone (group 2) deteriorated the surface properties of the lavage fluid, too. The effect of the phospholipid-poor alveolar lavage supernatant on the surface properties of surfactant from normal animals was investigated using a pulsating bubble technique. The lavage supernatant from hypoxanthine and $\mathrm{O}_{2}$-treated animals and, to some extent, also from only $\mathrm{O}_{2}$-treated animals (group 2) inhibited surface activity, whereas the lavage supernatant from normal animals had no significant effect on the in vitro performance of surfactant.

\section{DISCUSSION}

In the present report we demonstrate that the combination of hypoxanthine and oxygen is more damaging to the rat lung than oxygen alone. The mechanism for this is speculative. It is known that hypoxanthine and $\mathrm{O}_{2}$ can create the $\mathrm{O}_{2}{ }^{-}$radical in the presence of xanthine oxidase. There is evidence, however, that xanthine oxidase in vivo exists as a dehydrogenase. Because superoxide dismutase, a free radical scavenger, completely abolishes xanthine $\rightarrow$ cytochrome $C$ activity of both the dehydrogenase and oxidase type of xanthine oxidase, it is apparent, however, that in both cases the reaction is mediated by $\mathrm{O}_{2}^{-}$radical (37). Superoxide dismutase catalyses the transformation of $\mathrm{O}_{2}{ }^{-}$ to $\mathrm{H}_{2} \mathrm{O}_{2}$. Further $\mathrm{O}_{2}^{-}$can react and form the radical $\mathrm{OH} \cdot(8$, 19). Free radicals with a very short half-life cannot be measured in vivo but their significance can be further assessed indirectly by introducing a free radical scavenger, for instance superoxide dismutase or catalase. It will be of interest to study whether a scavenger could have a protective effect in our model, which would give further evidence that free oxygen radicals damage the lung. The rat was chosen as an experimental animal because its lung contains xanthine oxidase in contrast to humans $(1,36)$. There is, however, evidence that xanthine oxidase is quite easily released from the liver of sick adult humans (29) and could thus react with hypoxanthine in any part of the body to create oxygen radicals. Plasma xanthine oxidase has, however, not yet been determined in sick newborn infants.

With the appearance of leukocytes in the lung of rats given 
Table 3. Distribution of alveolar lavage phospholipids

\begin{tabular}{|c|c|c|c|c|}
\hline Phospholipid \% of total & $\begin{array}{l}\text { Group 1 } \\
(n=10)\end{array}$ & $\begin{array}{c}\text { Group 2 } \\
(n=9)\end{array}$ & $\begin{array}{c}\text { Group } 3 \\
(n=4)\end{array}$ & $\begin{array}{c}\text { Group } 4 \\
(n=7)\end{array}$ \\
\hline Phosphatidylcholine & $78.0 \pm 4.0^{*}$ & $79.8 \pm 2.8^{*}$ & $80.0 \pm 4.9^{*}$ & $79.8 \pm 2.6^{*}$ \\
\hline Sphingomyelin & $2.7 \pm 2.2$ & $1.4 \pm 0.4$ & $1.8 \pm 0.5$ & $1.7 \pm 0.7$ \\
\hline Phosphatidylinositol & $4.0 \pm 1.9$ & $4.0 \pm 2.6$ & $4.3 \pm 0.9$ & $4.1 \pm 3.0$ \\
\hline Phosphatidylglycerol & $9.6 \pm 4.0$ & $9.2 \pm 2.0$ & $9.0 \pm 1.7$ & $9.4 \pm 1.5$ \\
\hline $\begin{array}{l}\text { Phosphatidylethanolamine }+ \\
\text { phosphatidylserine }\end{array}$ & $4.0 \pm 2.1$ & $3.7 \pm 2.0$ & $4.0 \pm 1.7$ & $3.7 \pm 0.3$ \\
\hline $\begin{array}{l}\text { Bis(monoacylglycerol)-phos- } \\
\text { phate }\end{array}$ & $1.7 \pm 0.2$ & $1.9 \pm 0.5$ & $0.9 \pm 0.5$ & $1.3 \pm 0.8$ \\
\hline Total & 100 & 100 & 100 & 100 \\
\hline $\begin{array}{l}\text { Disaturated phosphatidylcho- } \\
\text { line/Total phosphatidylcho- } \\
\text { line } \times 100\end{array}$ & $71.0 \pm 14.0$ & $71.0 \pm 17.0$ & $70.0 \pm 15.1$ & $77.0 \pm 14.0$ \\
\hline $\begin{array}{l}\text { Disaturated phosphatidylcho- } \\
\text { line/sphingomyelin } \times 100\end{array}$ & $25.5 \pm 11.2$ & $35.3 \pm 14.9$ & $30.0 \pm 4.9$ & $26.2 \pm 3.2$ \\
\hline
\end{tabular}

${ }^{*}$ Mean $\pm \mathrm{SD}$. There was no significant differences between the groups.

Table 4. Minimum surface tension $(d y n / \mathrm{cm}$ ) (values given as mean $\pm S D$

\begin{tabular}{|c|c|c|c|}
\hline & $\begin{array}{c}\text { Crude alveolar } \\
\text { lavage }\end{array}$ & $\begin{array}{l}\text { Surfactant } \\
\text { complex }\end{array}$ & $\begin{array}{c}\text { Normal surfactan } \\
+ \text { protein rich } \\
\text { fraction of } \\
\text { alveolar lavage* }\end{array}$ \\
\hline $\begin{array}{l}\text { Group 1 } \\
\quad(n=4)\end{array}$ & $14.5 \pm 4.2^{* *}$ & $2.9 \pm 1.2$ (N.S.) & $15 \pm 4 \S$ \\
\hline $\begin{array}{l}\text { Group 2 } \\
\quad(n=4)\end{array}$ & $7.0 \pm 5.2^{* *}$ & $2.2 \pm 0.8$ (N.S.) & $7 \pm 3 \S$ \\
\hline $\begin{array}{l}\text { Group } 3 \\
\quad(n=4)\end{array}$ & $2.9 \pm 7.0$ (N.S.) & $2.9 \pm 4.2$ (N.S.) & $4 \pm 4$ (N.S.) \\
\hline $\begin{array}{l}\text { Group } 4 \\
\quad(n=4)\end{array}$ & $3.5 \pm 2.0$ & $1.9 \pm 1.0$ & $3 \pm 1$ \\
\hline
\end{tabular}

* Alveolar lavage was centrifuged at $9000 \mathrm{~g}$ for $90 \mathrm{~min}$. The proteinrich supernatant was freeze-dried and $25 \%$ of the orignal volume of water was added to the residue. One volume of this mixture was added to one volume of the suspension of normal rabbit surfactant containing $2 \mathrm{nmol}$ of disaturated phosphatidylcholine $/ \mu \mathrm{l}$ of $3 \mathrm{mM} \mathrm{CaCl}$. The minimum surface tension was measured using a pulsating bubble surfactometer (Surfactometer International, Toronto, Canada) as described by Enhörning (6). ${ }^{* *} P<0.05$ and $\S P<0.02$. Group 1 vs $2, P<0.05(t$ test).

hypoxanthine and $\mathrm{O}_{2}$ we examined bronchoalveolar lavage fluid for the presence of free elastase. We were unable to demonstrate any free elastase in this study. There is, however, a possibility that elastase binds to the tissues in the lungs so as not to be free for lavaging but still is present as an active proteolytic enzyme.

In contrast, $\alpha-1-\mathrm{PI}$ was elevated in hypoxanthine and $\mathrm{O}_{2}$ treated animals. This high level could be a reflection of a higher plasma level. Because the total protein level was increased in lavage fluid as well, we cannot conclude that the $\alpha$-1-PI elevation was specific. We could not find evidence for inactivation of $\alpha-1$ PI by oxidation. We still believe that such oxidation can take place, the entrance of $\alpha-1-\mathrm{PI}$ into the pulmonary tissue with edema fluid occurring so fast, however, that there is no time for oxidants to affect the methionine residues in the $\alpha-1-\mathrm{PI}$.

We found a normal alveolar lavage phospholipid pattern in hypoxanthine and $\mathrm{O}_{2}$-treated rats whereas the surfactant activity was reduced. The surfactant fraction of the protein-rich fraction inhibited normal surfactant. This implies that a normal, mature lung phospholipid profile (17) may not necessarily mean that the surfactant is able to adequately stabilize the peripheral airways. This may become a significant problem only as a result of damage of the alveolar epithelium, and contamination of the alveolar spaces with protein-rich material that inhibits the surface activity. It was suggested more than a decade ago that surfactant inhibition occurs (28), and recent evidence indicates that surfactant is inhibited in immature lambs (15) treated with exogeneous surfactant, oxygen and artificial ventilation. Our data demonstrate that similar inhibition can occur in mature rat lungs, despite apparently normal surfactant phospholipids.

The destruction of tissue by hypoxanthine and $\mathrm{O}_{2}$ could illustrate a general principle in medicine. According to the present hypothesis hypoxanthine increases free radicals. Especially when extra oxygen is given for treatment of hypoxia, large amounts of oxygen free radicals could be formed. This mechanism could, at least partly, explain the pathogenesis of several ill-understood conditions. In neonatology, diseases worthwhile to consider could be acute lung damage in premature infants with respiratory distress syndrome and after given artificial ventilation, chronic bronchopulmonary dysplasia. It is worthwhile to investigate whether this could be an important pathogenetic mechanism in necrotizing enterocolitis, retrolental fibroplasia and intraventricular/subependymal hemmorhage found in the premature baby.

It is of interest to mention that transfused blood contains large amounts of hypoxanthine $(2,31)$. The number of blood transfusions in the premature baby has often been suggested as an etiologic factor for developing the conditions mentioned above.

\section{REFERENCES AND NOTES}

1. Al-Khalidi, U. A. S. and Chaglassian, T. H.: The species distribution of xanthine oxidase. Biochem. J., 97: 318 (1965).

2. Brandt Petersen, B., Jørni, J., and Jørgensen, S.: Hypoxanthine, xanthine and uric acid in human urine and in decomposed blood. Scand. J. clin. Lab. Invest., 17: 460 (1965).

3. Burls, R. F., Lawrence, R. A., and Love, M. M.: Liver necrosis and lipid peroxidation in the rat as a result of paraquat and diquat administration. Effect of selenium defeciency. J. Clin. Invest., 65: 1024 (1980).

4. Castillo, M. J., Nakajima, K., Zimmerman, M., and Powers, J. C.: Sensitive substrates for human leukocyte and porcine pancreatic elastase: a study of the merits of various chromophoric and fluorogenic leaving groups in assays for serine proteases. Anal. Biochem., 99: 53 (1979).

5. Cohen, A. B.: The effect in vivo and in vitro of oxidative damage to purified alpha $_{1}$-antitrypsin and to the enzyme inhibiting activity of plasma. Am. Rev. Respir. Dis., 119: 953 (1979).

6. Enhörning, G.: A pulsating bubble technique for evaluating pulmonary surfactant. J. Appl. Physiol., 43: 198 (1977).

7. Fridovich, I.: Quantitative aspects of the production of superoxide anion radical by milk xanthine oxidase. J. Biol. Chem., 25: 4053 (1970).

8. Fridovich, I.: The biology of oxygen radicals. Science, 201: 875 (1978).

9. Hallman, M. and Gluck, L.: Formation of acidic phopholipids in rabbit lung during perinatal development. Pediatr. Res., 14: 1250 (1980).

10. Hallman, M., Spragg, R., Harell, J. H., Moser, K. M., and Gluck, L.: Evidence of lung surfactant abnormality in respiratory failure. Study of bronchoalveo- 
lar lavage phospholipids, surface activity, phospholipase activity, and plasma myoinositol. J. Clin. Invest., 70: 673 (1982).

11. Hannah, R. S. and Hannah, K. J.: Hyperoxia: effects on the vascularization of the developing central nervous system. Acta Neuropathol. (Berlin), 5I: 141 (1980).

12. Harkness, R. A. and Lund, R. J.: Cerebrospinal fluid concentrations of hypoxanthine, xanthine, uridine and inosine:high concentrations of the ATP metabolite, hypoxanthine, after hypoxia. J. Clin. Pathol., 36: 1 (1983).

13. Hildebran, J. N., Goerke, J., and Clements, J. A.: Pulmonary surface film stability and composition. J. Appl. Physiol., 43: 198 (1977).

14. Huber, G. L. and Drath, D. B.: Pulmonary oxygen toxicity. In: D. L. Gilbert: Oxygen and living processes. pp 272-342 (Springer Verlag, New York, Heidelberg, Berlin 1981).

15. Ikegami, M., Jobe, A., and Glatz, T.: Surfactant activity following natural surfactant treatment of premature lambs. J. Appl. Physiol., 51: 306 (1981)

16. Johnson, K. J., Fanton, J. C., Kaplan, J., and Ward, P.: In vivo damage of rat lungs by oxygen metabolites. J. Clin. Invest., 67: 983 (1981).

17. Kulovich, M. V., Hallman, M., and Gluck, L.: The lung profile. 1. Normal pregnancy. Am. J. Obst. Gynecol., 135: 57 (1979).

18. Levine, E. A., Senior, R. M., and Butler, J. V.: The elastase activity of alveolar macrophages.: measurements using synthetic substrates and elastin. Am. Rev. Respir. Dis., 113: 24 (1976).

19. Lewis, D. L. and Del Maestro, R.: Free radicals in medicine and biology. Acta Physiol. Scand. (suppl.) 492 (1979).

20. Lowry, O. H., Rosenbrough, N. J., and Farr, A. L.: Protein measurements with the folin phenol reagent. J. Biol. Chem., 193: 265 (1951).

21. Lunch, R. E. and Fridovich, I.: Effects of superoxide on the erythrocyte membrane. J. Biol. Chem., 253: 1838 (1978).

22. Del Maestro, R. F. Björk, J., and Arfors, K.-E.: Increase in microvascular permeability induced by enzymatically generated free radicals. Microvas. Res., 22: 255 (1981).

23. Manzke, H., Dörner, K., and Grünitz, J.: Urinary hypoxanthine, xanthine, and uric acid excretion in newborn infants with perinatal complications. Acta Paediatr. Scand., 66: 713 (1976).

24. Mason, R. J. Nellenbogen, J., and Clements, J. A.: Isolation of disaturated phosphatidylcholine with osmium tetroxide. N. Eng. J. Med., 288: (1973).

25. Meberg, A. and Saugstad, O. D.: Hypoxanthine in cerebrospinal fluid in children. Scand. J. Clin. Lab. Invest., 57: 281 (1978).
26. Pannell, R., Johnson, D., and Troois, J.: Isolation and properties of human plasma a-1-proteinase. Biochemistry, 13: 5439 (1974).

27. Phelps, D. L.: Neonatal oxygen toxicity. Is it preventable? In: W. Oh: Symposium on the newborn. Pediat. Clin. N. Am., 29: 1233 (1982).

28. Said, I. S., Avery, M. E., Davis, R. K., Banerjee, C. M., and Gohary, M.: Pulmonary surface activity in induced pulmonary edema. J. Clin. Invest., 44: 458 (1965).

29. Shammea, M. H., Nashrullah, S. M., and Al-Khalidi, U. A. S.: Serum xanthine oxidase. Am. J. Digest. Dis., 18: 15 (1973).

30. Saugstad, O. D.: Hypoxanthine as a measurement of hypoxia. Pediatr. Res., 9: $158(1975)$.

31. Saugstad, O. D.: The determination of hypoxanthine with a $\mathrm{pO}_{2}$-electrode. Pediatr. Res., 9: 575 (1975).

32. Saugstad, O. D. and Gluck, L.: Plasma hypoxanthine levels in newborn infants: A specific indicator of hypoxia. J. Perinat. Med., 10:266 (1982).

33. Saugstad, O. D. and Schrader, H.: The determination of inosine and hypoxanthine in rat brain during normothermic and hypothermic anoxia. Acta Neurol. Scand., 57: 281 (1978)

34. Swanström, S. and Bratteby, L. E.: Hypoxanthine as a test of perinatal hypoxia as compared to lactate, base deficit and pH. Pediatr. Res., 16:156 (1982).

35. Thiringer, K.: Cord plasma hypoxanthine as a measure of foetal asphyxia. Acta Paediatr. Scand., 72: 231 (1983).

36. Watts, R. W. E., Watts, J. E. M., and Seegmiller, J. E.: Xanthine oxidase activity in human tissues and its inhibition by allopurinol (4-hydroxypyrezolo (3,4-d)Pyrimidine). J. Lab. Clin. Med., 66: 688 (1965).

37. Waud, W. R. and Rajagopalan, K. V.: Purification and properties of the NAD ${ }^{+}$ dependant (type $\mathrm{D}$ ) and $\mathrm{O}_{2}$-dependant (type $\mathrm{O}$ ) forms of rat liver xanthine dehydrogenase. Archiv. Biochem. Biophys., 172: 354 (1976).

38. Wung, W. E. and Howell, S. B.: Simultaneous liquid chromatography of 5fluorouracil, uridine, hypoxanthine, xanthine, uric acid, allopurinol and oxypurinol in plasma. Clin. Chem., 26: 1704 (1980).

39. Requests for reprints should be addressed to: Dr. O. D. Saugstad, Department of Pediatrics, Rikshospitalet, Oslo 1, Norway.

40. This research was supported by USPHS grants: FO5 TWO2934, HD 10622, HD 04380, The American-Scandinavian Foundation, and the Norwegian Research Council for Science and the Humanities.

41. Received for publication March 24, 1983.

42. Accepted for publication August 9, 1983.

\title{
Kinetics of Uptake of L-Leucine and Glycylsarcosine into Normal and Protein Malnourished Young Rat Jejunum
}

\author{
P. M. MILLER, ${ }^{(20)}$ D. BURSTON, M. J. BRUETON, ${ }^{(21)}$ AND D. M. MATTHEWS \\ Department of Experimental Chemical Pathology, Vincent Square Laboratories of Westminster Hospital and \\ Department of Child Health, Westminster Medical School, London, England
}

\section{Summary}

The impact of malnutrition on peptide and amino acid absorption has been studied in the immediate postweaning period. At this time peptide uptake is quantitatively more important than amino acid uptake and the vulnerability of the infant to malnutrition is great. Everted rings of rat jejunum were used to investigate the uptake of the peptide glycylsarcosine (Gly-Sar) and the amino acid L-leucine. The animals had been weaned on to isocaloric diets containing $18 \%$ or $4 \%$ protein. The rats deprived of protein at this age showed a marked growth disturbance with considerable reduction in gut length in addition to poor weight gain. Mediated influx of Gly-Sar and leucine per centimeter of jejunum was reduced in the malnourished animals: $V_{\max }, 77 \pm$ 7.1 (SEM) and $65 \pm 3.6$ compared with $85 \pm 10.6$ and $77 \pm 4.4$ $\mathrm{nmol} \cdot \mathrm{min}^{-1} \cdot \mathrm{cm}^{-1} \cdot$, respectively. But, when expressed in relation to body weight, the maximal transport capacity showed a marked increase with malnutrition, values being 126 and $111 \mathrm{nmol}^{-1}$. $\mathrm{cm}^{-1} \cdot 100 \mathrm{~g}^{-1}$ body weight compared with 39 and $35 \mathrm{nmol}^{-1}$. $\mathrm{cm}^{-1} \cdot 100 \mathrm{~g}^{-1}$ body weight for Gly-Sar and leucine respectively.

\section{Abbreviation}

Gly-Sar, glycylsarcosine

The onset of malnutrition in the immediate postweaning period in infancy is a common problem in the non-industrialised world. One of the crucial factors determining the malnourished infants potential for catch-up growth is the capacity to absorb 